\title{
Quantitative study of Chlamydia trachomatis in genital infection
}

\author{
H MALLINSON,* O P ARYA,† AND A D GODDARD \\ From the *Regional Public Health Laboratory, the +University Department of Venereology, Royal \\ Liverpool Hospital, and the $¥$ Computer Laboratory, University of Liverpool, Liverpool
}

SUMMARY Chlamydia trachomatis inclusion counts on inoculated McCoy cell coverslips were used as an index of the degree of infection of the cervix in women and of the urethra in men with $=$. urethritis. High inclusion counts were obtained significantly more often from men than from ${ }^{\infty}$ women, from women with cervical ectopy, and from women who had had recent sexual inter- $\vec{\omega}$ course. Low inclusion counts were significantly more common in men with a past history of gonococcal urethritis.

Higher chlamydial isolation rates in women with gonorrhoea and in women taking the con- $\vec{T}$ traceptive pill could not be attributed to a greater degree of infection, since inclusion counts wereo not raised in these patients. There was evidence that strains of $C$ trachomatis might vary in their ability to establish themselves in the genital tract because high counts in men with NGU were associated with high counts in their female consorts and the levels of counts in men were associated $\vec{c}_{0}$ with the frequency of chlamydial isolation from their female consorts.

The relatively simple technique of inclusion counts in cultures for chlamydia from the genitalo tract may yield valuable information about the behaviour of different strains of $C$ trachomatis in causing pathological changes, in the transmission of infection between individuals, and in the response to specific chemotherapy.

\section{Introduction}

When Chlamydia trachomatis is grown in McCoy cell tissue culture the number of intracellular inclusion bodies that develop after 2-3 days directly reflects the number of viable particles in the original inoculum. Inclusion counts in cultures from the genital tract may thus be used to assess the degree of infection. ${ }^{1}$ In a survey of patients attending a sexually transmitted diseases (STD) clinic we have graded chlamydiapositive cultures into those with low, high, or very high inclusion counts and related these to epidemiological and clinical aspects of the infections.

\section{Patients and methods}

STUDY POPULATION

This comprised all men with urethritis and all women who attended the STD clinic at St James's Hospital, Birkenhead, on Monday afternoons or Thursday

\footnotetext{
Address for reprints: Dr $\mathbf{H}$ Mallinson, Regional Public Health Laboratory, Fazakerley Hospital, Lower Lane, Liverpool L9 7AL

Accepted for publication 23 August 1981
}

mornings from January 1976 to September $1978 \stackrel{\overrightarrow{0}}{3}$ Patients who had received an antibiotic or sulphonamide in the past month and men who hae reported urethritis within the past three months were excluded.

\section{CLINICAL AND CULTURAL TECHNIQUES}

Demographic data, past history, history of recenê exposure, symptoms, and signs were recorded on precoded proformas. Details of the examination of female patients and cultural methods, including thes isolation of $C$ trachomatis on idoxuridine-treated. McCoy cell coverslips, have been described. ${ }^{2}$ Urethral swabs from men were cultured for Neisseriq gonorrhoeae and $C$ trachomatis and used to prepare smears for identifying pus cells and Gram-negativew intracellular diplococci. Urethritis was diagnose when smears showed $\geqslant 15$ polymorphonuclearo leucocytes (PMNL) in each of five microscope fieldsD ( $\times 100$ objective, $\times 6.3$ eye-pieces).

CHLAMYDIAL INCLUSION COUNTS Chlamydia-positive coverslips $(12 \mathrm{~mm}$ in diameter $)$ were graded as showing low or high inclusion count $\$$ 
by scanning across several diameters with the $\times 20$ objective and $\times 10$ eye-pieces of the dark-ground microscope. Under these conditions each traverse of a coverslip diameter covered one twenty-fourth part of the whole coverslip area.

Low counts: Less than 5 inclusions per diameter was equivalent to $<120$ inclusions per whole coverslip; such coverslips were graded as giving low inclusion counts.

High counts: Coverslips with $\geqslant 5$ inclusions per diameter ( $\geqslant 120$ inclusions per coverslip) were graded as giving high inclusion counts.

Very high counts: Some coverslips had many inclusions in every microscope field (one nine-hundredth of the coverslip area); those with $\geqslant 5$ inclusions per field were graded as giving very high $(\geqslant 4500)$ inclusion counts.

\section{STATISTICAL ANALYSIS}

The data were analysed with a computer using the 'statistical package for social sciences'. Tests of significance were performed by the $\chi^{2}$ method applying Yates's correction where appropriate. ${ }^{4}$

\section{Results}

$C$ trachomatis was isolated from 147 of $474(31 \%)$ women and from 191 of $413(46 \%)$ men with urethritis. Inclusion counts were performed on a random selection of 115 women and 181 men (tables I and II). Overall, high counts $(\geqslant 120)$ were found in about half $(156$ or $53 \%)$ and very high counts $(\geqslant 4500)$ in almost one-fifth (52 or 18\%) of these 296 positive coverslips. Swabs with high counts were obtained significantly more often from the chlamydia-positive men with urethritis $(57 \%)$ than from the chlamydiapositive women $(45 \%)\left(\chi_{1}^{2}=4 \cdot 23, \mathrm{P}<0 \cdot 05\right)$.

\section{WOMEN}

The distribution of inclusion counts was not affected by age, marital state, or stage of menstrual cycle.

Although isolation rates for chlamydia were significantly higher $\left(\chi_{1}^{2}=13 \cdot 3, \mathrm{P}<0.001\right)$ in those using oral contraceptives $(40 \%$ chlamydia-positive) than in those not practising contraception $(21 \%$ chlamydiapositive) the use of oral contraceptives did not influence the incidence of high inclusion counts. An

TABLE I Factors studied in relation to $C$ trachomatis inclusion counts in women

\begin{tabular}{|c|c|c|c|c|c|c|c|}
\hline \multirow{3}{*}{$\begin{array}{l}\text { Factor examined } \\
\text { All women } \\
\text { Age (years) }\end{array}$} & \multirow{3}{*}{$\begin{array}{l}\text { Total No } \\
\text { of patients }\end{array}$} & \multicolumn{6}{|c|}{ No $(\%)$ of patients with following inclusion counts: } \\
\hline & & \multicolumn{2}{|c|}{$\begin{array}{l}\text { Low } \\
(<120)\end{array}$} & \multicolumn{2}{|c|}{$\begin{array}{l}\text { High } \\
\geqslant I 20)\end{array}$} & \multicolumn{2}{|c|}{$\begin{array}{l}\text { Very high } \\
\geqslant 4500)\end{array}$} \\
\hline & & 63 & (55) & 52 & (45) & 17 & (15) \\
\hline $\begin{array}{l}\text { Age (years) } \\
15-19 \\
20-29 \\
\geqslant 30\end{array}$ & $\begin{array}{l}33 \\
68 \\
14\end{array}$ & $\begin{array}{r}19 \\
36 \\
8\end{array}$ & $\begin{array}{l}(58) \\
(53) \\
(57)\end{array}$ & $\begin{array}{r}14 \\
32 \\
6\end{array}$ & $\begin{array}{l}(42) \\
(47) \\
(43)\end{array}$ & $\begin{array}{l}6 \\
9 \\
2\end{array}$ & $\begin{array}{l}(18) \\
(13) \\
(14)\end{array}$ \\
\hline \multicolumn{8}{|c|}{ Contraceptive method } \\
\hline $\begin{array}{l}\text { Pill } \\
\text { None }\end{array}$ & $\begin{array}{l}82 \\
21\end{array}$ & $\begin{array}{l}44 \\
13\end{array}$ & $\begin{array}{l}(54) \\
(62)\end{array}$ & $\begin{array}{r}38 \\
8\end{array}$ & $\begin{array}{l}(46) \\
(38)\end{array}$ & $\begin{array}{r}11 \\
3\end{array}$ & $\begin{array}{l}\text { (13) } \\
\text { (14) }\end{array}$ \\
\hline \multicolumn{8}{|l|}{ Last intercourse } \\
\hline $\begin{array}{l}<1 \text { week } \\
1-2 \text { weeks } \\
\geqslant 3 \text { weeks }\end{array}$ & $\begin{array}{l}37 \\
53 \\
25\end{array}$ & $\begin{array}{l}12 \\
29 \\
22\end{array}$ & $\begin{array}{l}(32) \\
(55) \\
(88)\end{array}$ & $\begin{array}{r}25 \\
24 \\
3\end{array}$ & $\begin{array}{l}(68) \\
(45) \\
(12)\end{array}$ & $\begin{array}{l}8 \\
8 \\
1\end{array}$ & $\begin{array}{r}(22) \\
(15) \\
(4)\end{array}$ \\
\hline \multicolumn{8}{|l|}{ Cervical ectopy } \\
\hline $\begin{array}{l}\text { Absent } \\
\text { Simple } \\
\text { Hypertrophic }\end{array}$ & $\begin{array}{l}29 \\
43 \\
43\end{array}$ & $\begin{array}{l}21 \\
24 \\
18\end{array}$ & $\begin{array}{l}(72) \\
(56) \\
(42)\end{array}$ & $\begin{array}{r}8 \\
19 \\
25\end{array}$ & $\begin{array}{l}(28) \\
(44) \\
(58)\end{array}$ & $\begin{array}{l}2 \\
5 \\
9\end{array}$ & $\begin{array}{l}\text { (7) } \\
(12) \\
(21)\end{array}$ \\
\hline \multicolumn{8}{|l|}{$T$ vaginalis } \\
\hline $\begin{array}{l}\text { Present } \\
\text { Absent }\end{array}$ & $\begin{array}{l}18 \\
97\end{array}$ & $\begin{array}{l}14 \\
49\end{array}$ & $\begin{array}{l}(78) \\
(51)\end{array}$ & $\begin{array}{r}4 \\
48\end{array}$ & $\begin{array}{l}(22) \\
(49)\end{array}$ & $\begin{array}{r}2 \\
15\end{array}$ & $\begin{array}{l}(11) \\
(16)\end{array}$ \\
\hline \multicolumn{8}{|l|}{ Candidosis } \\
\hline $\begin{array}{l}\text { Present } \\
\text { Absent }\end{array}$ & $\begin{array}{l}19 \\
96\end{array}$ & $\begin{array}{l}11 \\
52\end{array}$ & $\begin{array}{l}(58) \\
(54)\end{array}$ & $\begin{array}{r}8 \\
44\end{array}$ & $\begin{array}{l}(42) \\
(46)\end{array}$ & $\begin{array}{r}3 \\
14\end{array}$ & $\begin{array}{l}\text { (16) } \\
\text { (15) }\end{array}$ \\
\hline \multicolumn{8}{|l|}{ Gonorrhoea } \\
\hline $\begin{array}{l}\text { Present } \\
\text { Absent }\end{array}$ & $\begin{array}{l}47 \\
68\end{array}$ & $\begin{array}{l}25 \\
38\end{array}$ & $\begin{array}{l}(53) \\
(56)\end{array}$ & $\begin{array}{l}22 \\
30\end{array}$ & $\begin{array}{l}(47) \\
(44)\end{array}$ & $\begin{array}{r}6 \\
11\end{array}$ & $\begin{array}{l}(13) \\
\text { (16) }\end{array}$ \\
\hline \multicolumn{8}{|c|}{$\begin{array}{l}\text { Cervical mucopus: } \\
\text { With gonorrhoea }\end{array}$} \\
\hline $\begin{array}{l}\text { Present } \\
\text { Absent }\end{array}$ & $\begin{array}{l}13 \\
34\end{array}$ & $\begin{array}{r}4 \\
21\end{array}$ & $\begin{array}{l}(31) \\
(62)\end{array}$ & $\begin{array}{r}9 \\
13\end{array}$ & $\begin{array}{l}(69) \\
(38)\end{array}$ & $\begin{array}{l}2 \\
4\end{array}$ & $\begin{array}{l}(15) \\
(12)\end{array}$ \\
\hline $\begin{array}{l}\text { Without gonor } \\
\text { Present } \\
\text { Absent } \\
\text { Residual symptor } \\
\text { for gonorrho }\end{array}$ & $\begin{array}{l}17 \\
51\end{array}$ & $\begin{array}{r}9 \\
29\end{array}$ & $\begin{array}{l}(53) \\
(57)\end{array}$ & $\begin{array}{r}8 \\
22\end{array}$ & $\begin{array}{l}(47) \\
(43)\end{array}$ & $\begin{array}{l}3 \\
8\end{array}$ & $\begin{array}{l}\text { (18) } \\
\text { (16) }\end{array}$ \\
\hline
\end{tabular}


TABLE II Factors studied in relation to $C$ trachomatis inclusion counts in men with urethritis

\begin{tabular}{|c|c|c|c|c|c|c|c|}
\hline \multirow{3}{*}{ Factor examined } & \multirow{3}{*}{$\begin{array}{l}\text { Total No } \\
\text { of patients }\end{array}$} & \multicolumn{6}{|c|}{ No (\%) of patients with following inclusion counts: } \\
\hline & & \multicolumn{2}{|c|}{$\begin{array}{l}\text { Low } \\
(<120)\end{array}$} & \multicolumn{2}{|c|}{$\begin{array}{l}\text { High } \\
\text { (>120) }\end{array}$} & \multicolumn{2}{|c|}{$\begin{array}{l}\text { Very high } \\
\text { (>4500) }\end{array}$} \\
\hline & & 77 & (43) & 104 & (57) & 35 & (19) \\
\hline $\begin{array}{l}\text { Age (years) } \\
15-19 \\
20-29 \\
\geqslant 30 \\
\text { Men with }\end{array}$ & $\begin{array}{r}22 \\
108 \\
51\end{array}$ & $\begin{array}{r}5 \\
51 \\
21\end{array}$ & $\begin{array}{l}(23) \\
(47) \\
(41)\end{array}$ & $\begin{array}{l}17 \\
57 \\
30\end{array}$ & $\begin{array}{l}(77) \\
(53) \\
(59)\end{array}$ & $\begin{array}{r}7 \\
19 \\
9\end{array}$ & $\begin{array}{l}(32) \\
(18) \\
(18)\end{array}$ \\
\hline NGU & $\begin{array}{r}45 \\
136\end{array}$ & $\begin{array}{l}22 \\
55\end{array}$ & $\begin{array}{l}(49) \\
(40)\end{array}$ & $\begin{array}{l}23 \\
81\end{array}$ & $\begin{array}{l}(51) \\
(60)\end{array}$ & $\begin{array}{r}6 \\
29\end{array}$ & $\begin{array}{l}(13) \\
(21)\end{array}$ \\
\hline $\begin{array}{l}\text { Past history of NGU* } \\
\text { Present } \\
\text { Absent }\end{array}$ & $\begin{array}{r}53 \\
127\end{array}$ & $\begin{array}{l}24 \\
53\end{array}$ & $\begin{array}{l}(45) \\
(42)\end{array}$ & $\begin{array}{l}29 \\
74\end{array}$ & $\begin{array}{l}(55) \\
(58)\end{array}$ & $\begin{array}{l}10 \\
25\end{array}$ & $\begin{array}{l}(19) \\
(20)\end{array}$ \\
\hline $\begin{array}{l}\text { Past history of } \mathrm{GU}^{*} \\
\text { Present } \\
\text { Absent }\end{array}$ & $\begin{array}{r}43 \\
137\end{array}$ & $\begin{array}{l}24 \\
53\end{array}$ & $\begin{array}{l}(56) \\
(39)\end{array}$ & $\begin{array}{l}19 \\
84\end{array}$ & $\begin{array}{l}(44) \\
(61)\end{array}$ & $\begin{array}{r}3 \\
32\end{array}$ & $\begin{array}{l}(7) \\
(23)\end{array}$ \\
\hline $\begin{array}{l}\text { Men with NGU whose consorts were: } \\
\text { Chlamydia - } \\
\text { Chlamydia }+(<120) \\
\text { Chlamydia }+(120-4500) \\
\text { Chlamydia }+(>4500)\end{array}$ & $\begin{array}{r}14 \\
9 \\
8 \\
5\end{array}$ & $\begin{array}{l}9 \\
4 \\
3 \\
1\end{array}$ & $\begin{array}{l}(64) \\
(44) \\
(38) \\
(20)\end{array}$ & $\begin{array}{l}5 \\
5 \\
5 \\
4\end{array}$ & $\begin{array}{l}(36) \\
(56) \\
(62) \\
(80)\end{array}$ & $\begin{array}{l}1 \\
2 \\
3 \\
2\end{array}$ & $\begin{array}{r}(7) \\
(22) \\
(38) \\
(40)\end{array}$ \\
\hline
\end{tabular}

+ Positive; - negative; NGU = non-gonococcal urethritis; $\mathrm{GU}=$ gonococcal urethritis

* Information not recorded for one patient

effect of recent intercourse was seen in that high counts $\left(\chi_{1}^{2}=11 \cdot 0, P<0.001\right)$ or very high counts $\left(\chi_{1}^{2}=4 \cdot 21, P<0 \cdot 05\right)$ were obtained significantly more often compared with low counts in those who reported intercourse within the previous week.

High counts were significantly associated with the presence of ectopy ('erosion') $\left(\chi_{1}^{2}=3.96, \mathrm{P}<0.05\right)$, with very high counts being found more frequently in patients whose ectopy was hypertrophic.

Low counts were more common in those with concurrent Trichomonas vaginalis infection than in those without $\left(\chi_{1}^{2}=3.51, \mathrm{P}>0.05\right)$ but counts were not affected by concurrent Candida infection. Although isolation rates for chlamydia were significantly higher $\left(\chi_{1}^{2}=16 \cdot 2, \mathrm{P}<0.001\right)$ in those with gonorrhoea ( $44 \%$ chlamydia-positive) than in those without ( $25 \%$ chlamydia-positive), the distribution of inclusion counts was unaffected by concurrent gonococcal infection. In women with gonorrhoea, however, cervical mucopus was associated with high counts, but these were not found in the presence of mucopus without gonococcal infection. Women who complained of persistent residual symptoms after treatment for gonorrhoea included more with high counts initially than those in whom symptoms resolved quickly.

MEN

High counts were more common in men under 20 years than in those over, but the difference was not significant $\left(\chi_{1}^{2}=3 \cdot 16, \mathrm{P}>0 \cdot 05\right)$. In men with nongonococcal urethritis (NGU) high and very high counts were more frequent than in those with gonococcal urethritis (GU) but the difference was not significant. In both groups a past history of NGU dign not affect the distribution of counts but a history of GU was associated with a reduction in the frequenc $5_{00}^{\circ}$ of high counts $\left(\chi_{1}^{2}=3.91, \mathrm{P}<0.05\right)$ or very high ${ }^{\mathrm{N}}$ counts $\left(\chi_{1}^{2}=4 \cdot 61, \mathrm{P}<0 \cdot 05\right)$.

In men with NGU, high counts were associated with high counts in their female consorts. There waš also a link between counts in men and the frequencso of chlamydial isolation from their female consorts $\mathbb{Q}$ Of eight men with very high counts, seven $(\mathbf{8 8 \%})$ had consorts infected with C trachomatis; of 11 men with high but not very high counts, seven $(64 \%)$ hadb infected consorts; of 17 men with low counts, eight (47\%) had infected consorts.

\section{Discussion}

Chlamydia trachomatis is an organism that is commonly transmitted by sexual intercourse ande from mothers to new-born infants. It causes urethritis in men, conjunctivitis and pneumonitis in? babies, and infection of the genital tract in women which is often symptomless and not associated with any detectable pathological lesion. It is clearlyo important to establish whether the numbers ofw chlamydia present in various infected or carrier sites have a bearing on the pathology and epidemiology of $C$ trachomatis infection.

Hilton et $a l^{5}$ found that women taking oraf contraceptives had a significantly higher proportion of specimens with more than 100 inclusions per? coverslip than did women not taking the contraceptive pill. In a study of women consorts of men̊ 
with NGU, Tait et $a l^{6}$ found higher mean inclusion counts to be associated with the use of oral contraceptives or the presence of endocervical mucopus but not with hypertrophic ectopy. In a much larger study, however, Hobson et al ${ }^{1}$ confirmed the association of high counts $(>1000)$ with cervical mucopus but found in contrast that high counts were associated with the presence of cervical ectopy but not directly with the use of the contraceptive pill. Our present results support this latter finding of high counts in those with cervical ectopy and a lack of effect on the count of the contraceptive pill. The tendency to find high counts in those with cervical mucopus was apparent only in women with gonorrhoea. A reported association of high counts with younger age in women ${ }^{1}$ was not confirmed in this study, although a similar trend was suggested in men with urethritis. The significantly higher chlamydial isolation rates in women with gonorrhoea and those taking the contraceptive pill could not be attributed to a greater degree of infection since inclusion counts were not found to be raised in these patients.

In men it is not clear why fewer high counts were obtained from patients with a history of gonococcal but not non-gonococcal urethritis. There was an association between high counts in men and in their female consorts and between inclusion counts in men and the frequency with which chlamydia were isolated from their female consorts. This suggests that some strains of $C$ trachomatis may establish themselves in the genital tract more readily than others and this may be a factor determining the numbers of organisms present.
The estimation of inclusion counts would be unlikely to improve the routine management of individual patients with STD. A knowledge of both isolation rates and the distribution of inclusion counts in a patient population should, however, allow a clearer understanding of $C$ trachomatis infections. It may yield valuable information on the effect of strain variation in causing pathological changes in the genital or respiratory tracts, on the transmission of infection from one individual to another, on the response to specific chemotherapy, and on the relation to other features in the genital tract, such as associated infections including gonorrhoea, trichomoniasis, and candidosis.

We are indebted to Dr G C Turner for help and advice in preparing the manuscript.

\section{References}

1. Hobson D, Karayiannis P, Byng RE, Rees E, Tait IA, Davies J. Quantitative aspects of chlamydial infection of the cervix. $B r$ $J$ Vener Dis 1980;56: 156-62.

2. Arya OP, Mallinson H, Goddard AD. Epidemiological and clinical correlates of chlamydial infection of the cervix. $B r J$ Vener Dis 1981;57:118-24.

3. Mallinson H, Sikotra S, Arya OP. A cultural method for largescale screening for Chlamydia trachomatis genital infection. $J$ Clin Pathol 1981;34:712-8.

4. Swinscow TDV. Statistics at square one: XV The $\chi^{2}$ tests (continued). Br Med J 1976; ii:513-4.

5. Hilton AL, Richmond SJ, Milne JD, Hindley F, Clarke SKR. Chlamydia $\mathrm{A}$ in the female genital tract. Br J Vener Dis 1974;50: 1-10.

6. Tait IA, Rees E, Hobson D, Byng RE, Tweedie MCK. Chlamydial infection of the cervix in contacts of men with nongonococcal urethritis. Br J Vener Dis 1980;56:37-45. 